\title{
Synthesis of the Benz[a]anthraquinone Core of Angucyclinone Antibiotics
}

\author{
Aris Kalogerakis and Ulrich Groth* \\ Fachbereich Chemie, Universität Konstanz, Fach M-720, Universitaetsstrasse 10, \\ 78457 Konstanz, Germany \\ ulrich.groth@uni-konstanz.de
}

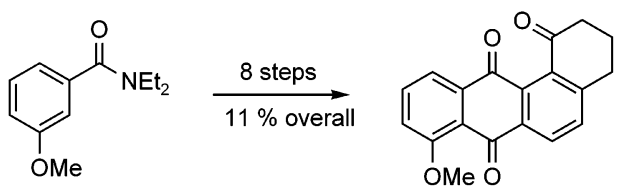

A general method for the synthesis of benz[a]anthraquinones is reported. The key step is a catalytic cobalt-mediated [2+2+2]-cycloaddition of a triyne, which affords an angularly substituted tetracycle. Oxidation of this core gives the typical structure of angucyclinone antibiotics.

The angucyclines are a large class of antibiotics isolated from several strains of Streptomyces. They display a broad spectrum of biological properties including antiviral, antifungal, antitumor, and enzyme inhibitor activity. ${ }^{1}$ Most of these antibiotics feature a unique benz $[a]$ anthraquinone structure either with or without a 9- $C$-glycosidic moiety. Members of this class of angucyclines without a glycosidic moiety, the angucyclinones, have the benz $[a]$ anthraquinone structure either without a hydroxy group at C-6 such as (+)rubiginone $\mathrm{B}_{2} \mathbf{1}^{2}$ or with a hydroxy group at C-6 such as (+)-hatomarubigin A 2. ${ }^{3}$ Some members of this class feature a tertiary hydroxy group at C-3 such as (-)-tetrangomycin $\mathbf{3}^{4}$ and (-)-rabelomycin $\mathbf{4 .}^{5}$

Most general strategies for the construction of the angucyclinone framework are based on Diels-Alder reaction of a naphthoquinone with a vinylcyclohexene ${ }^{6}$ or on biomi-

(1) (a) Rohr, J.; Thiericke, R. Nat. Prod. Rep. 1992, 103-137. (b) Krohn, K.; Rohr, J. Top. Curr. Chem. 1997, 188, 127-195.

(2) Oka, M.; Kamei, H.; Hamagishi, Y.; Omita, K.; Miyaki, T.; Konish, M.; Oki, T. J. Antibiot. 1990, 43, 967-976.

(3) Hayakawa, Y.; Ha, S.-C.; Kim, Y. L.; Furihata, K.; Sato, H. J. Antibiot. 1991, 44, 1179-1186.

(4) Kunstmann, M. P.; Mitscher, L. A. J. Org. Chem. 1996, 31, 29202925.

(5) Liu, W.-C.; Parker, W. L.; Slusarchyk, D. S.; Greenwood, G. L.; Graham, S. F.; Meyers, E. J. Antibiot. 1970, 23, 437-441.

(6) (a) Carreño, M. C.; Urbano, A.; Vitta, C. D. Chem. Commun. 1999, 817-818. (b) Carreño, M. C.; Urbano, A.; Vitta, C. D. Chem. Eur. J. 2000, 6, 906-913. (c) Larsen, D. S.; O’Shea, M. D.; Brooker, S. Chem. Commun. 1996, 203-204. (d) Boyd, V. A.; Sulikowski, G. A. J. Am. Chem. Soc. 1995, $117,8472-8473$. metic-type reactions ${ }^{7}$ by employing polyketide condensations.<smiles>[R]c1cc2c(c3c1C(=O)c1c(OC)cccc1C3=O)C(=O)C[C@@H](C)C2</smiles>

(+)-rubiginone $\mathrm{B}_{2} \mathrm{R}=\mathrm{H} 1$ (+)-hatomarubigin $\mathrm{A} \mathrm{R}=\mathrm{OH} 2$<smiles>[R]c1cc2c(c3c1C(=O)c1c(O)cccc1C3=O)C(=O)C[C@@](C)(O)C2</smiles>

(-)-tetrangomycin $\mathrm{R}=\mathrm{H} 3$ (-)-rabelomycin $\mathrm{R}=\mathrm{OH} 4$
Herein we would like to present the first synthesis of the benz $[a]$ anthraquinone structure of the angucyclinone antibiotics via an intramolecular cobalt-mediated $[2+2+2]$ cycloaddition $^{8}$ of a triyne. The cyclization of triynes is a powerful synthetic method to form several carbon-carbon bonds in one step and provides access to polycyclic systems with a newly formed highly substituted benzene nucleus. We were able to synthesize a triyne-precursor 11 (Scheme 1) which, after cobalt-mediated $[2+2+2]$-cycloaddition, gave the anthracene structure 13 (Scheme 2). ${ }^{9}$ Cyclization experiments with $\mathrm{RhCl}\left(\mathrm{PPh}_{3}\right)_{3}$ and $\mathrm{RuCl}_{2}(=\mathrm{CHPh})\left(\mathrm{PCy}_{3}\right)_{2}$, which

(7) (a)Yamaguchi, M.; Okuma, T.; Horiguchi, C.; Ikeura, C.; Minami, T. J. Org. Chem. 1992, 57, 1647-1649. (b) Krohn, K.; Böker, N.; Flörke, U.; Freund, C. J. Org. Chem. 1997, 62, 2350-2356.

(8) (a) Vollhardt, K. P. C. Angew. Chem., Int. Ed. Engl. 1984, 23, 539644. (b) Malacria, M. Chem. Rev. 1996, 96, 289-306.

(9) Transition Metal Catalyzed Reactions in Organic Synthesis, Part 3. For Part 2, see: Fischer, S.; Groth, U.; Jung, M.; Schneider, A. Synlett 2002, 2023-2026. 


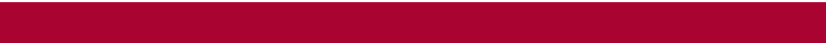

Scheme $1^{a}$

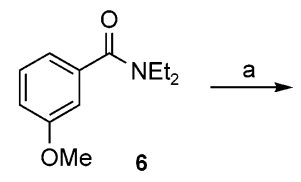

$\underbrace{=}_{\mathrm{OMe}}{ }_{7 M S}^{\stackrel{\mathrm{CEt}}{=}}$
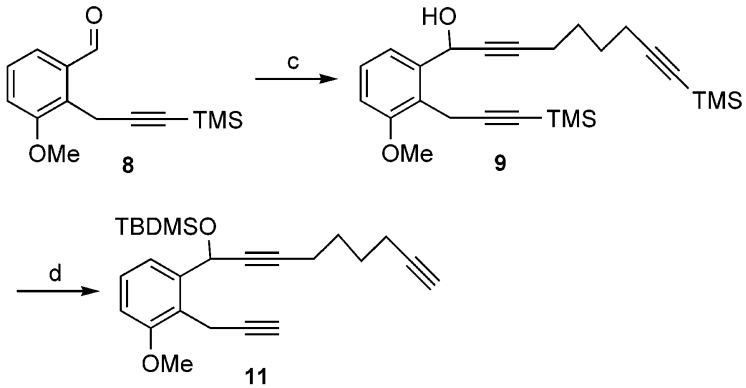

${ }^{a}$ Reagents and conditions: (a) (i) $s$-BuLi/TMEDA, THF, -80 ${ }^{\circ} \mathrm{C}, 1 \mathrm{~h}$, (ii) $\mathrm{ZnCl}_{2},-80{ }^{\circ} \mathrm{C}, 1 \mathrm{~h}$, (iii) $\mathrm{CuCN} \cdot 2 \mathrm{LiCl},-80^{\circ} \mathrm{C}, 1 \mathrm{~h}$, (iv) (3-bromoprop-1-ynyl)trimethylsilane $5,-80{ }^{\circ} \mathrm{C}$ to room temperature (85\%). (b) DIBAL/BuLi, THF, $25^{\circ} \mathrm{C}, 18 \mathrm{~h}$ (68\%). (c) BuLi/ 1-TMS-1,7-octadiyne, THF (82\%). (d) (i) $\mathrm{NH}_{4} \mathrm{~F} / \mathrm{Bu}_{4} \mathrm{NHSO}_{4}, \mathrm{CH}_{2} \mathrm{Cl}_{2}$, $48 \mathrm{~h}$, (ii) TBDMSOTf, 2,6-lutidine, $\mathrm{CH}_{2} \mathrm{Cl}_{2}, 25^{\circ} \mathrm{C}, 2 \mathrm{~h}(95 \%)$.

can also promote alkyne trimerization, ${ }^{10}$ were not successful in our systems. Two-step oxidation of $\mathbf{1 3}$ led then to the angucyclinone core $\mathbf{1 5}$.

The amide $\mathbf{6}^{11}$ was at first selectively ortho-lithiated with $s$-BuLi/TMEDA. ${ }^{12 \mathrm{~b}}$ It was then transmetalated with $\mathrm{ZnCl}_{2}$ and then $\mathrm{CuCN} \cdot 2 \mathrm{LiCl}$ and allowed to react with (3bromoprop-1-ynyl)trimethylsilane $\mathbf{5}$ to give the propynylamide $7 .^{12 \mathrm{c}}$ This was directly reduced to benzaldehyde $\mathbf{8}$ with the DIBAL/BuLi complex. ${ }^{13}$ After addition of lithiated 1-TMS-1,7-octadiyne ${ }^{14}$ to this aldehyde, the triple bonds of the resulting triyne 9 were deprotected with $\mathrm{NH}_{4} \mathrm{~F}^{15}$ (deprotection with TBAF in THF led to decomposition of the triyne 9). The hydroxy group was then transformed into its silyl ether 11 with the aid of TBDMSOTf. ${ }^{16}$

For the cyclization of $\mathbf{1 1}$ we used $\mathrm{CpCo}(\text { ethene })_{2}{ }^{17}$ and the commercially available $\mathrm{CpCo}(\mathrm{CO})_{2}$. Reaction of $\mathbf{1 1}$ with $5 \%$ $\mathrm{CpCo}$ (ethene $)_{2}$ succeeded under mild conditions at low temperature. Surprisingly we observed the loss of the TBDMSO-group with concomitant aromatization to the

(10) (a) Witulski, B.; Stengel, T. Angew. Chem., Int. Ed. 1999, 38, 24262430. (b) Neeson, S. J.; Stevenson, P. J. Tetrahedron 1989, 45, 62396248. (c) Blechert, S.; Peters, J. U. Chem. Commun. 1997, 1983-84.

(11) Brimble, M. A.; Robinson, S. G. Tetrahedron 1996, 52, 95539562.

(12) (a) Kreye, P. Ph. D Thesis, University of Goettingen (F.R.G.), 1996. (b) Snieckus, V. Chem. Rev. 1990, 90, 0, 879-933. (c) Singer, P. D.; Knochel, P. Chem. Rev. 1993, 93, 2117-2188.

(13) Kim, S.; Ahn, K. H. J. Org. Chem. 1984, 49, 1717-1724

(14) Rudisill, D. E.; Stille, J. K. J. Org. Chem. 1989, 54, 5856-5866.

(15) Herold, P. Helv. Chim. Acta 1986, 71, 354-356.

(16) Corey, E. J.; Cho, H.; Ruecker, C.; Hua, D. H. Tetrahedron Lett. 1981, 36, 3455-3458.

(17) (a) Jonas, K.; Deffense, E.; Habermann, D. Angew. Chem., Int. Ed. Engl. 1983, 22, 716. (b) Eichberg, M. J.; Dorta, R. L.; Lamottke, K.; Vollhardt, K. P. C. Org. Lett. 2000, 16, 2479-2481. (c) Eichberg, M. J.; Dorta, R. L.; Grotjahn, D. B.; Lamottke, K.; Schmidt, M.; Vollhardt, K. P. C. J. Am. Chem. Soc. 2001, 123, 9324-9337. (d) Cammack, J. K.; Jalisatgi, S.; Matzger, A. J.; Negrón, A.; Vollhardt, K. P. C. J. Org. Chem. 1996, 61, $4798-4800$

\section{Scheme $2^{a}$}
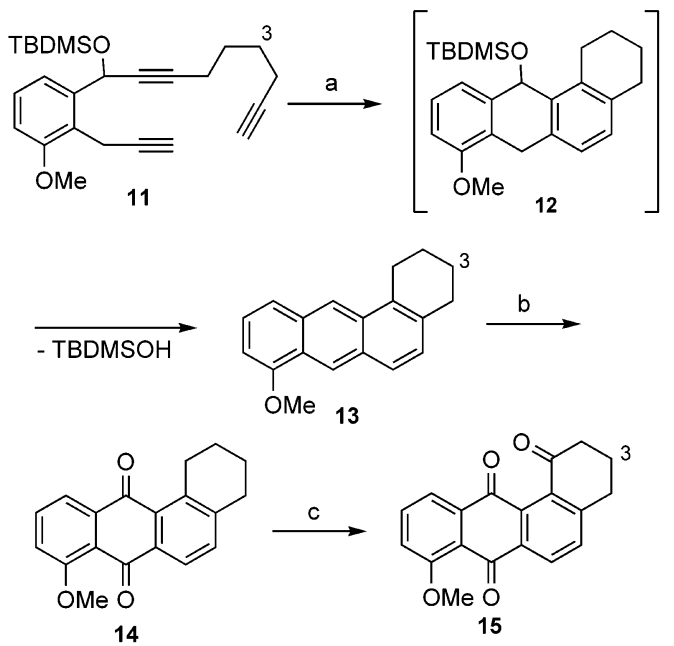

${ }^{a}$ Reagents and conditions: (a) $5 \% \mathrm{CpCo}$ (ethene) $)_{2}, \mathrm{Et}_{2} \mathrm{O},-80$ ${ }^{\circ} \mathrm{C}$ to room temperature, $18 \mathrm{~h}$, or $5 \% \mathrm{CpCo}(\mathrm{CO})_{2}$, toluene, reflux, $h v, 4 \mathrm{~h}(66 \%)$. (b) 8 equiv of $\left[\mathrm{Ag}(\mathrm{Py})_{2}\right] \mathrm{MnO}_{4}, \mathrm{CH}_{2} \mathrm{Cl}_{2}, 25^{\circ} \mathrm{C}, 18$ h (63\%). (c) $h v$, air, $\mathrm{CHCl}_{3}, 25^{\circ} \mathrm{C}, 18 \mathrm{~h}(61 \%)$.

anthracene 13 (55\% yield and 16\% isolated starting material). In the case of $\mathrm{CpCo}(\mathrm{CO})_{2}$ the reaction had been carried out in toluene under reflux and irradiation with a tungsten lamp (66\% yield). Oxidation of $\mathbf{1 3}$ with the aid of the mild reagent $\left[\mathrm{Ag}(\mathrm{Py})_{2}\right] \mathrm{MnO}_{4}$ gave the anthraquinone $\mathbf{1 4}(63 \%$ yield $){ }^{18}$ We have also been trying to oxidize with $\mathrm{CrO}_{3}$ in $\mathrm{AcOH}$, but these conditions led to decomposition of the anthracene. The introduction of the C-1 carbonyl was achieved by photooxidation, a general method for the angucyclinones developed by Krohn. ${ }^{19}$ Exposure of $\mathbf{1 4}$ to visible light (tungsten lamp) gave the typical structure $\mathbf{1 5}$ of the angucyclinone antibiotics (61\% yield).

In conclusion, the angucyclinone framework $\mathbf{1 5}$ was synthesized from benzamide 6 in 8 steps and 11\% yield overall. This method provides a new access toward the angucyclinone antibiotics, which do not have a hydroxy group at C-6. The stereocenter at C-3 is not involved in the $[2+2+2]$-cycloaddition, therefore this methodology offers a good strategy for the enantioselective synthesis of this class of antibiotics.

Acknowledgment. The authors are grateful to the Fonds der Chemischen Industrie and the EU-Comission, Directorate XII, for financial support.

Supporting Information Available: Experimental procedures and analytical data for all compounds, ${ }^{1} \mathrm{H}$ NMR and ${ }^{13} \mathrm{C}$ NMR spectra for $\mathbf{1 3}, \mathbf{1 4}$, and $\mathbf{1 5}$. This material is available free of charge via the Internet at http://pubs.acs.org.

OL0274920

(18) Tius, M. A.; Galeno, J. G.; Gu, X.; Zaid, J. H. J. Am. Chem. Soc. 1991, 113, 5775-5783.

(19) (a) Krohn, K.; Ballwanz, F.; Baltus, W. Liebigs Ann. Chem. 1993 911-913. (b) Krohn, K.; Micheel, J.; Zukowski, M. Tetrahedron 2000, 56, 4753-4758. (c) Caygill, G. B.; Larsen, D. S.; Brooker, S. J. Org. Chem. 2001, 66, 7427-7431. (d) Mal, D.; Roy, H. N. J. Chem. Soc., Perkin Trans. 1 1999, 3167-3171. (e) Carreño, M. C.; Ribagorda, M.; Somoza, A. Urbano, A. Angew. Chem., Int. Ed. 2002, 41, 2755-2757. 